\title{
Externalities and House Prices: A Stated Preferences Approach
}

\author{
Michał Głuszak
}

\begin{abstract}
A B S T R A C T
Objective: In the article, we address the nexus between neighbourhood externalities and house prices using stated preference data. The impact of neighbourhood amenities generating positive externalities and disamenities generating negative externalities on property prices has been studied since the 1970s. Most of the studies to date applied the hedonic methodology and assumed that the effect is homogeneous. The article aims to address the potential heterogeneity of housebuyers' preferences.

Research Design \& Methods: The article uses logistic regression models on stated preference data regarding the sensitivity to three spatial amenities (public transit, urban green area, and retail and services) and three spatial disamenities (railway line, noisy road, petrol station). The dataset comes from six editions of the survey on housing demand and preferences in Krakow conducted annually from 2012 to 2017.
\end{abstract}

Findings: Empirical results show the relation between household lifecycle and household wealth and willingness-to-pay for spatial amenities and willingness-toaccept spatial disamenities. We did not observe the difference in preferences dependent on the purchase motive.

Implications \& Recommendations: The results can be interesting for planners and policymakers, but also in the business environment in case of residential development.

Contribution \& Value Added: The article fills the gap in the economic literature on factors affecting housebuyers' sensitivity to certain positive and negative externalities that manifest in stated willingness-to-pay and willingness-to-accept.

\begin{tabular}{ll}
\hline Article type: & research article \\
Keywords: & externalities; house price; hedonic; stated preferences \\
JEL codes: & D62, R21, R32
\end{tabular}

Received: 13 September $2018 \quad$ Revised: 31 October $2018 \quad$ Accepted: 16 November 2018

\section{Suggested citation:}

Głuszak, M. (2018). Externalities and House Prices: A Stated Preferences Approach. Entrepreneurial Business and Economics Review, 6(4), 181-196. https://doi.org/10.15678/EBER.2018.060410 


\section{INTRODUCTION}

Mainstream economic literature was abundant of examples of positive and negative externalities that resulted from conforming and nonconforming functions of adjacent property. One of the best examples is Meade's orchard and hive (Johnson, 1973; Meade, 1952).

The nexus between various spatial (dis)amenities and property prices has been the subject of economic investigation since the seminal contributions to the theory of the demand for complex goods made by Lancaster (1966) and Rosen (1974). It is difficult to list all objects that can decrease property prices nearby, but examples include industrial facilities, nuclear plants, energy lines, wind turbines, waste management facilities, or even places linked with criminal activity. The list of amenities that can increase property prices in the vicinity is equally impressive. The prior research focused on public transport, urban green, public services, recreation areas. It is safe to say that to date thousands of empirical papers using hedonic regression have been published to address these issues.

In the article, we address the importance of several (dis)amenities on housing choices of potential housebuyers in Krakow, one of the most developed property markets in Poland. In the article, we focus on stated-preference data using survey data collected annually at the housing fair from 2012 to 2017 . The objective of the article is to investigate the role of housebuyers' characteristics in willingness-to-pay for spatial amenities and willingness-to-accept spatial disamenities. In particular, in the article we test three hypotheses using stated preference data:

1. Hypothesis 1. Preferences regarding the proximity of neighbourhood (dis)amenities are dependent on the housing purchase motive (investment vs consumption).

2. Hypothesis 2. Preferences regarding the proximity of neighbourhood (dis)amenities change with housebuyers' age.

3. Hypothesis 3. Preferences regarding the proximity of neighbourhood (dis)amenities change with housebuyers' economic status.

The article is organised as follows. In the following section we analyse prior literature addressing the links between the presence of several amenities and disamenities and property prices. Within the same section, we assess the use of stated and revealed preference methods. In section 3 we discuss the method and preference data, and we describe independent variables used in the study. In section 4 we examine the empirical results of logit model estimation and discuss the implications and limitations of the study. In section 5 we comment on the findings, reflect on research goals and hypotheses.

\section{LITERATURE REVIEW}

\section{Externalities and Real Estate Value}

Externalities are considered one of the main reasons for a market failure. The externalities occur when given economic activity has consequences (costs and benefits) for unrelated third parties (individuals or organisations). Based on the nature of consequences economics distinguishes between positive and negative externalities. Examples of negative externalities on the property market are environmental consequences of industrial activity (noise, pollution) that affect the nearby residence (Źróbek et al., 2015). These 
negative externalities through the property market mechanism (supply and demand) are later discounted in house prices in the vicinity of the pollutant. On the contrary, a new railway line can increase the accessibility of a given area, and generate a positive externality. Many externalities on the property market manifest spatially, as their impact diminishes with the distance from the source.

Prior research on the link between externalities and property prices historically focused on selected neighbourhood effects. It is extremely difficult to enumerate all types of objects generating positive and negative externalities that could affect property prices, but examples include public transportation, industrial facilities, green areas, schools, and airports. In the article, we briefly summarise the latest research regarding the willingness-to-pay (implicit price) for the proximity to urban green areas, public transportation, public and private services, railway lines, road noise, and detrimental industrial/commercial activity.

An empirical investigation on the nexus between urban green and real estate markets yields mostly consistent results regarding the positive impact of the proximity of green areas on property prices (Gómez-Baggethun \& Barton, 2013, p. 8). The economic literature suggests that due to various positive externalities (recreation possibilities, health benefits, comforting shade, pleasant view, noise reduction) that dominate over potential nuisances the presence of green areas results in an increase in property prices in the neighbourhood. It should be noted, however, that the size effect found in relevant research papers is heterogeneous.

Since pioneer studies conducted in the 1960s and 1970s (Hendon, 1971; Knetsch, 1964) most of the economic studies conducted in the US suggested a significant positive relationship between the proximity to green areas and real estate values. Most recent examples include Irwin (2002), Thorsnes (2002) and Conway et al. (2010). Results from European studies are generally in line with the US literature. Examples include empirical research from Austria (Herath, Choumert, \& Maier, 2015), Finland (Tyrväinen \& Miettinen, 2000; Votsis, 2017), Germany (Ahlfeldt \& Maennig, 2013; Kolbe \& Wüstemann, 2014), Israel (Cohen, 2016), Poland (Czembrowski \& Kronenberg, 2016; Trojanek, Głuszak, \& Tanaś, 2018) and Portugal (Franco \& Macdonald, 2016). This overwhelming consistent picture is confirmed in empirical studies in major metropolitan areas in Asia. Among many recent empirical papers that yield similar results are studies conducted in Hong Kong (Jim \& Chen, 2010), Beijing (Biao, Gaodi, Bin, \& Canqiang, 2012) or Tokyo (Hoshino \& Kuriyama, 2010).

There are some exceptions to this generally consistent evidence. The contradictory evidence is due to two negative externalities arising from the presence of green areas in the vicinity of the property. Firstly, in some special cases (mostly remote rural locations in warm, arid climate zones, like some parts of Portugal, Spain, Australia or California) green areas are vulnerable to wildfires that can spread to surrounding areas. This type of catastrophic risk can have a detrimental effect on the demand for property in the impact area, and as a consequence lead to the price decrease. Secondly, in other cases (most densely populated urban areas) urban green may attract unwelcomed activity - drug traffic, alcoholism, theft, vandalism - that creates obvious negative externalities for all citizens and businesses located in the neighbourhood. The market consequence of the latter is a decrease in property prices (Crompton, 2001; Troy, Grove, \& Grove, 2008).

Based on the classic urban theories, built on the concept of central location, that can be traced back to the works of von Thunen, Alonso, Muth and Mills, economic liter- 
ature investigated the relations between public transportation and property values. Since the pioneer work of Deweess (1976), traditionally a body of empirical evidence on the links between rapid public transit and property prices comes from major metropolitan areas in the US (McMillen \& McDonald, 2004; Kim \& Lahr, 2014) and Canada (Dube, Theriault, \& Des Rosiers, 2013). The topic was also investigated in South America, based on case studies of the subway in Santiago, Chile (Agostini \& Palmucci, 2008), and rapid bus in Bogota, Columbia (Rodriguez \& Targa, 2004). There are also numerous studies on the economic impact of public transportation in Europe. Amongst the most empirical evidence on the positive impact of the accessibility of public transit on property prices are studies on: suburban railways in the Netherlands (Debrezion, Pels, \& Rietveld, 2011), metro in Santander, Spain (Ibeas, Cordera, Dell'Olio, Coppola, \& Dominguez, 2012), subway in Warsaw (Trojanek \& Głuszak, 2018), various types of public transit in Dublin (Mayor, Lyons, Duffy, \& Tol, 2012), and last but not least two studies on the famous London uderground (Gibbons \& Machin, 2005; Ahlfeldt, 2013). Finally, there is a growing body of evidence on public transportation in developing Asian cities, supporting the previous findings from mature urban areas in both Americas and Europe. The list includes research on the subway system in: Dubai (Mohammad, Graham, \& Melo, 2015), Seul (Bae, Jun, \& Park, 2003), Bangkok (Anantsuksomsri \& Tontisirin, 2015), Beijing (Chen \& Haynes, 2015) or Taipei (Liou, Yang, Chen, \& Hsieh, 2016).

There is a consensus that despite some negative externalities that can manifest in the proximity of stations (drug traffic, vandalism), and lines (noise, view disturbance) an increase in accessibility rises property users' utility. The latter would increase both the rent and prices of residential and commercial properties in the vicinity of public transit. The magnitude of the impact depends on various economic and cultural factors, thus the results of empirical investigation varied concerning the reported effect size, while remaining fairly unambiguous regarding the positive sign of the coefficients.

Another example of positive spatial amenities in an urbanised area are retail and services. The retail and services are an important factor behind urban development, and generally accessibility to services and shops increase residential satisfaction and decrease household overall commuting costs and time (Glaeser, Kolko, \& Saiz, 2001). Despite potential negative externalities most studies found that the accessibility of convenience stores as well as public services in most cases has a positive impact on house prices (Chiang, Peng, \& Chang, 2015; Jang \& Kang, 2015; Koster \& Rouwendal, 2012; Song \& Sohn, 2007).

Not all neighbourhood effects are positive, because some objects generate mostly negative externalities. Links between some of these spatial disamenities and property prices have been addressed in the economic literature. Critical reviews suggest that there are numerous examples of negative externalities related to spatial disamenities that has negative effect on property prices. Examples include landfills (Nahman, 2011), industrial facilities (Grislain-Letrémy \& Katossky, 2014), pollution (Guignet, Jenkins, Ranson, \& Walsh, 2018).

As it was argued before, intracity (commuter) rail increases the accessibility within metropolitan areas and can have a positive impact on property prices in the neighbourhoods within walking distance from the stations, similar to other rapid public transit modes (fast tram, fast bus, metro). At the same time, some studies suggested that there are several negative externalities generated by railway lines, that can lead to a price de- 
crease in the proximity of the railway line (Beimer \& Maennig, 2017). Most prolific examples are noise emission and view disturbance. The latter effect would manifest strongly in the first row of development, adjacent to the railway line (Portnov, Bella, \& Barzilay, 2009). There are several studies that show that specific effect in the proximity of lines and stations (Gatzlaff \& Smith, 1993; Martínez \& Viegas, 2009; Pan, 2013; Geng, Bao, \& Liang, 2015). It can be argued that properties directly exposed to the railway line would suffer from negative externalities. Additionally, in many cases railway line does not automatically increase accessibility - the examples include railway lines mostly used for cargo operations and rapid intercity connections. In these two latter cases, the lines have mostly a negative impact (a potential decrease in spatial accessibility, noise, view disturbance), and it would be reflected in the preferences of housebuyers (and property prices).

The same logic regarding the accessibility gains and negative externalities also applies to major roads, highways, and ring roads in the metropolitan area, due to extensive noise and pollution. Noise is widely considered as one of the negative externalities strictly linked to urbanisation and technological development. There are numerous sources of noise: roads, railways, aircrafts, but also nightlife and industrial activity. It is not difficult to argue that due to its spatial distribution, road traffic is one of the most disturbing sources of noise. A noise emission increase has adverse social and health consequences and in general decreases life satisfaction and utility from living/working in the impacted area. According to hedonic theory, lower quality of housing will be discounted in property prices. According to empirical research, road noise has a negative effect on housing prices but significantly lower than aircraft noise (Beimer \& Maennig, 2017). The evidence from other papers indicates that the impact of noise may not be linear, and may depend on property sub-markets considered (Theebe, 2004).

\section{The Empirical Challenges to Investigate the Impact of Externalities on Property Markets}

The traditional approach to address the importance of several amenities and disamenities on housing demand has long been a hedonic regression. The hedonic method conceptualised in the mid-1960s by Lancaster (1966) and later developed and operationalised in 1970 s by Rosen (1974), but the general idea of analysing the price of heterogeneous goods using their characteristics can be traced back to 1920 s (Colwell \& Dilmore, 1999).

The hedonic models allow to determine the value of key characteristics of differentiated goods or services (e.g. housing or land). This implicit value of attributes is not observed empirically, but the method relies on observable market transactions. Under the assumption of perfect information, both quality and price of goods sold are known, and the price can be decomposed into the implicit prices of separate characteristics (that determine the quality of the given product). The hedonic framework allows to indirectly observe the monetary trade-offs of buyers and sellers, or in other words to analyse the market preferences that are revealed by decisions made by individuals on the market (Revealed Preferences, RP). The hedonic models have been used successfully to investigate the impact of various structural, neighbourhood and location characteristics on real estate prices (Malpezzi, 2002; Sirmans, Macpherson, \& Zietz, 2005). The significant empirical effort has been made to estimate the implicit prices of selected spatial amenities and disamenities. Positive and negative externalities generated by the presence of certain objects in the proximity can be either capitalised or discounted in property values, and hedonic 
models were used to evaluate this monetary effect. In recent years, some economist discussed the theoretical foundations of the method and addressed the role of uncertainty and asymmetric information in the hedonic price formation. The problem has been studied in the literature both theoretically and empirically - see Pope (2008), Kumbhakar and Parmeter (2010) or Zhou, Gibler and Zahirovic-Herbert (2015).

The alternative to the RP method (mostly hedonic valuation) is based on so-called Stated Preferences (SP). Stated preference data is collected through quasi-experiments or surveys, and under specific conditions, they can yield comparable results (Whitehead, Pattanayak, Van Houtven, \& Gelso, 2008). The basic difference between SP and RP are fundamental data generating processes (Ben-Akiva et al., 2002). In the case of the former, they refer to hypothetical, future choices, whereas the latter reflects real, past decisions made by individuals or groups on the market (Timmermans, Molin, \& van Noortwijk, 1994). Each method has several advantages and disadvantages. In particular, in the housing market setting traditional RP method market choices are limited to the set of alternatives available on the market, and cannot be used to forecast demand for new, innovative products. In some cases the method is not efficient due to data limitation - the samples are small, and key variables correlated. Although the SP method may help to overcome these issues, it does come at a high cost. The main disadvantage of SP data is a hypothetical (and sometimes not fully realistic) nature of the decision that has not been fully confronted with budget constraints. Along with numerous examples of SP studies focusing on housing preferences on mature property markets in the US and Western Europe, the approach was used to investigate housing demand (Głuszak \& Marona, 2017), preferences regarding tenant-mix in shopping centres (Marona \& Wilk, 2016) and willingness-to-pay for green buildings certificates (Zieba, Belniak, \& Głuszak, 2013) in Poland.

Because of similar theoretical foundations and despite potential differences in estimates (Murphy, Allen, Stevens, \& Weatherhead, 2005; Shogren, Shin, Hayes, \& Kliebenstein, 1994), both methods can be combined successfully in a particular research context to investigate housing preferences (Adamowicz, Swait, Boxall, Louviere, \& Williams, 1997; de Koning, Filatova, \& Bin, 2017; MacDonald, Murdoch, \& White, 1987; Phaneuf, Taylor, \& Braden, 2013; Timmermans et al., 1994).

\section{MATERIAL AND METHODS}

In the research, we use stated preference (SP) data to examine the importance of several spatial amenities and disamenities in residential location choices. The dataset comes from 'The Survey on Housing Demand and Preferences in Krakow', conducted annually from 2012 to 2017 by Instytut Analiz Monitor Rynku Nieruchomosci mrn.pl. The survey was distributed during the Housing Fair in Krakow, a regular exhibition where residential developers present their new investments and clients have the opportunity to compare different projects in one place. The Housing Fair is the biggest event of that kind in Krakow and draws a large number of visitors recruiting from future housebuyers, willing to acquire a flat on the primary market. The sampling strategy was non-random, and possibly not fully representative in the statistical sense, thus a direct inference on the housing demand structure is problematic. Nonetheless, the dataset offers in-depth insights into the preferences of housebuyers. Due to a relatively stable structure of the questionnaire (only a fraction of questions were modified during the study period, and none of the key ques- 
tions analysed in this article) the dataset seems to fit the research objective of this study. Taking the account of missing data (due to not fully completed questionnaires,) the final sample size was 671 (103 questionnaires from 2012 edition of the survey, 86 from 2013, 115 from 2014, 123 from 2015, 127 from 2016, and 117 from 2017).

The dependent variable was based on the sensitivity of respondents to selected objects potentially generating externalities in the neighbourhood. Within this particular question design, the sensitivity of housebuyers to certain spatial amenities (generating positive externalities) and disamenities (generating negative externalities) could be observed based on responses to two questions regarding the willingness to pay or willingness to accept certain spatial objects in the proximity of the future flat.

To identify most important amenities, respondents were asked what the objects that must be located in the proximity of their future house are (Figure 1). According to pooled results from the 2012-2017 surveys, three most popular objects were: public transport (selected by $79.9 \%$ of respondents), urban green area (68.5\%), and retail and services $(57.9 \%)$.

To identify the most prolific disamenities, the respondents were asked what the objects they will not accept in the proximity of their future house are. According to pool results from the 2012-2017 surveys, three least popular objects were: a noisy road (not accepted by $66.7 \%$ respondents), a railway line (56.7\%), and a petrol station (43.1\%). The results are illustrated in the figure (Figure 2 ).

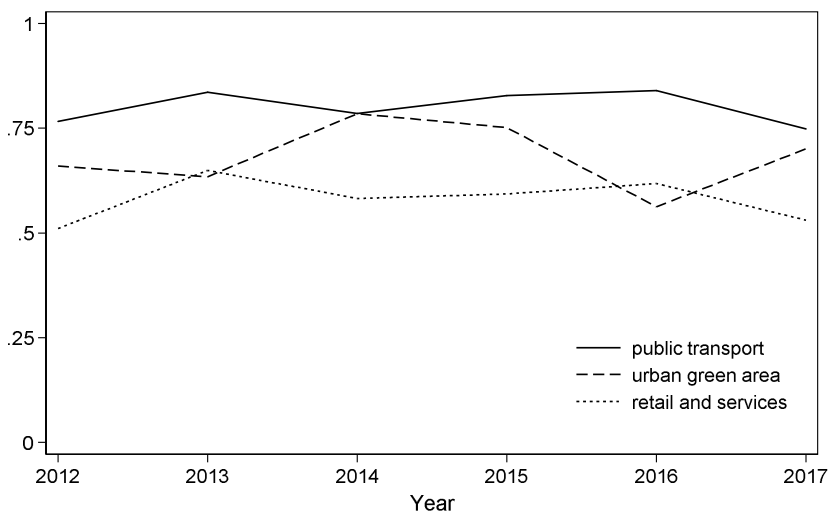

Figure 1. Major amenities in the proximity of a future house according to the responses of potential housebuyers in Krakow from 2012 to 2017 Source: own elaboration.

In the research, we investigate whether sensitivity to certain amenities or disamenities in the neighbourhood is related to certain characteristics of housebuyers (i.e. age, budget constraint), while controlling for consumption/investment motives (we distinguish future owners-occupiers from individuals willing to buy a flat for rental/speculation). The response variable is binary. It takes the value of 1 when the respondent selected a given amenity or disamenity from the list, and 0 otherwise. The selection of a given object indicates willingness-to-pay for amenities or reluctance-to-accept in case of disamenities. We used logistic regression to model the probability of a selection of (dis)amenities given a set of predictors. To test our hypothesis we used three independent variables - investment, 
age and price. The descriptive statistics for these variables are presented in the table (Table 1). Two major motives for housing purchase are consumption and investment (Arrondel \& Lefebvre, 2001; Brueckner, 1997). Although in many cases both motives are mixed, we separate all situations where respondents indicated that they plan to purchase a flat purely for investment purpose (rental, speculation or both). We use the investment variable to control for that, as we believe that these two groups can have different preferences and sensitivity to certain (dis)amenities.

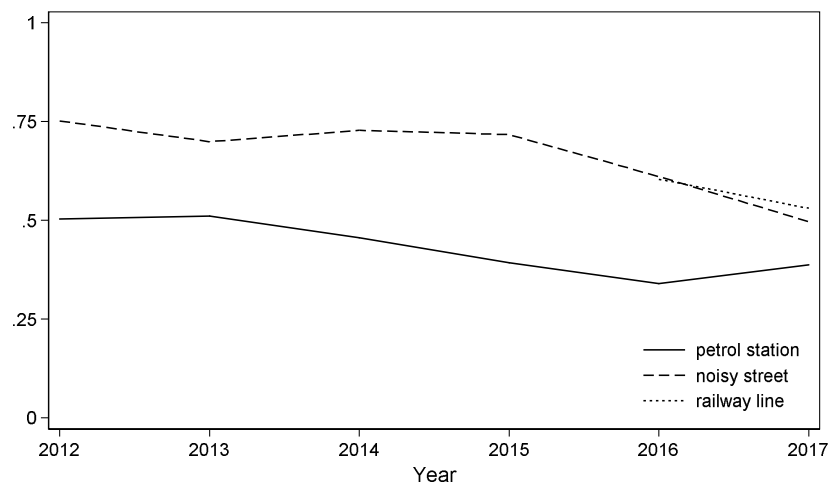

Figure 1. Major disamenities in the proximity of a future house according to the responses of potential housebuyers in Krakow from 2012 to 2017 Source: own elaboration.

Table 1. Descriptive statistics

\begin{tabular}{|l|l|c|c|c|c|}
\hline \multicolumn{1}{|c|}{ Variable } & \multicolumn{1}{|c|}{ Description } & Mean & Std. Dev. & Min & Max \\
\hline investment & $\begin{array}{l}\text { Qualitative, 1 if individual plans to buy a flat for } \\
\text { rental/speculation, 0 otherwise }\end{array}$ & 0.136 & 0.343 & 0 & 1 \\
\hline age & $\begin{array}{l}\text { Quantitative, Age of the household's head (in } \\
\text { years) }\end{array}$ & 31.823 & 8.453 & 18 & 70 \\
\hline price & $\begin{array}{l}\text { Quantitative, Maximum price household plan } \\
\text { spending for a future flat (in thousands PLN) }\end{array}$ & 360.204 & 136.750 & 50 & 1200 \\
\hline
\end{tabular}

Source: own study.

We controlled for budget constraints using price variable. We believe that households willing to spend more on housing (mostly wealthier households) may be more sensitive to neighbourhood effects. We use the age variable to control for age of the household head (the only variable available, to proxy for family lifecycle). We believe that sensitivity to certain amenities or disamenities can change with age. Finally, to take account of changing preferences and other time-varying conditions, we controlled for the year the survey was conducted using a set of Year ${ }_{t}$ dummy variables.

\section{RESULTS AND DISCUSSION}

Using the maximum likelihood, we estimated six logit models - three for amenities and three for disamenities. The estimation results for selected spatial amenities are presented in the table (Table 2). 
All three models have poor fit (pseudo R2 <0.05). It seems fairly clear that explanatory variables do not help to understand the propensity to choose selected spatial amenities as decisive decision factors when buying a flat. In particular, there is no significant difference between potential buyers expressing different investment motives (investment variable). In particular, respondents willing to buy a flat as a pure investment asset (speculation, rental) did not differ significantly from other households. The household head's age did not significantly change the probability to choose urban green and retail and services as decisive location factors.

Table 2. Logistic regression model for selected spatial amenities in the proximity of housing

\begin{tabular}{|l|c|c|c|c|c|c|}
\hline \multirow{2}{*}{ Variables } & \multicolumn{2}{|c|}{ Urban green } & \multicolumn{2}{c|}{ Public transport } & \multicolumn{2}{c|}{ Retail \& services } \\
\cline { 2 - 7 } & Exp(B) & Sig & Exp(B) & Sig & Exp(B) & Sig \\
\hline investment & 0.962 & & 0.995 & & 1.307 & \\
\hline & $(0.236)$ & & $(0.287)$ & & $(0.311)$ & \\
\hline age & 1.020 & & 0.978 & $* *$ & 1.002 & \\
\hline price & $(0.011)$ & & $(0.011)$ & & $(0.010)$ & \\
\hline & 1.003 & $* * *$ & 0.999 & & 1.000 & \\
\hline Year $_{2012}$ & $(0.001)$ & & $(0.001)$ & & $(0.001)$ & \\
\hline Year $_{2013}$ & base & & base & & base & \\
\hline & 0.824 & & 1.802 & & 1.712 & $*$ \\
\hline Year $_{2014}$ & $(0.255)$ & & $(0.707)$ & & $(0.520)$ & \\
\hline & 1.998 & $* *$ & 1.249 & & 1.508 & \\
\hline Year $_{2015}$ & $(0.623)$ & & $(0.419)$ & & $(0.421)$ & \\
\hline & 1.723 & $*$ & 1.683 & & 1.308 & \\
\hline Year 2016 & $(0.517)$ & & $(0.588)$ & & $(0.358)$ & \\
\hline & 0.721 & & 1.539 & & 1.478 & \\
\hline Year 2017 & $(0.202)$ & & $(0.525)$ & & $(0.403)$ & \\
\hline & 1.147 & & 0.934 & & 1.250 & \\
\hline Constant & $(0.338)$ & & $(0.298)$ & & $(0.344)$ & \\
\hline pseudo R2 $_{\text {N }}$ & 0.375 & $* *$ & 8.840 & $* * *$ & 0.888 & \\
\hline & $(0.186)$ & & $(4.726)$ & & $(0.395)$ & \\
\hline
\end{tabular}

Note: Standard errors in parenthesis; ${ }^{*} p<0.1,{ }^{* *}, p<0.05,{ }^{* * *} p<0.01$.

Source: own study.

We observed that age was significant in the case of public transit - in general an increase in age was linked with a decrease in the propensity to select this amenity. The reason behind that is a general increase in car dependence that is positively correlated with age (at least within the age brackets covered by our sample). In general, younger households are more dependent on public transportation, and more often travel by bus or tram. The price variable proved to be significant only in the case of urban green areas. Higher stated expenditures on housing increased the probability to choose urban green as an indispensable amenity in the proximity of their future house. It is worth noting; we observed some fluctuations in housing preferences over time (see significant coefficients for Year $_{\mathrm{t}}$ dummy variables). 
We applied a similar procedure in the case of spatial disamenities. The estimation results for selected spatial amenities are presented in the table (Table 3). The fit of the simple logit models for disamenities was rather poor (pseudo R2 was ranging from 0.01 to 0.05 ). Similarly to previous models for amenities, we can conclude that sensitivity to certain negative externalities cannot be comprehensively explained by demographic and economic factors.

Table 3. Logistic regression model for selected spatial disamenities in the proximity of housing

\begin{tabular}{|l|c|c|c|c|c|c|}
\hline \multirow{2}{*}{ Variables } & \multicolumn{2}{|c|}{ Petrol station } & \multicolumn{2}{c|}{ Noisy road } & \multicolumn{2}{c|}{ Railway line } \\
\cline { 2 - 7 } & Exp(B) & Sig & Exp(B) & Sig & Exp(B) & Sig \\
\hline investment & 0.955 & & 0.846 & & 1.837 & \\
\hline & $(0.229)$ & & $(0.204)$ & & $(0.697)$ & \\
\hline age & 1.055 & $* * *$ & 0.992 & & 0.987 & \\
\hline price & $(0.011)$ & & $(0.010)$ & & $(0.018)$ & \\
\hline & 1.001 & $* *$ & 1.001 & $* *$ & 1.001 & \\
\hline Year $_{2012}$ & $(0.001)$ & & $(0.001)$ & & $(0.001)$ & \\
\hline & base & & base & & - & \\
\hline Year 2013 & & & & & & \\
\hline & 1.116 & & 0.596 & & - & \\
\hline Year 2014 & $(0.342)$ & & $(0.201)$ & & & \\
\hline & 1.065 & & 0.777 & & - & \\
\hline Year 2015 & $(0.302)$ & & $(0.251)$ & & & \\
\hline & 0.797 & & 0.670 & & - & \\
\hline Year 2016 & $(0.224)$ & & $(0.210)$ & & & \\
\hline & 0.565 & $* *$ & 0.429 & $* * *$ & base & \\
\hline Year 2017 & $(0.161)$ & & $(0.130)$ & & & \\
\hline & 0.594 & & 0.286 & $* * *$ & 0.868 & \\
\hline Constant & $(0.170)$ & & $(0.088)$ & & $(0.234)$ & \\
\hline pseudo R2 & 0.098 & $* * *$ & 2.921 & $* *$ & 1.251 & \\
\hline N & $(0.046)$ & & $(1.439)$ & & $(0.891)$ & \\
\hline & 0.0500 & & 0.0330 & & 0.013 & \\
\hline & 671 & & 671 & & 244 & \\
\hline
\end{tabular}

Note: Standard errors in parenthesis; ${ }^{*} \mathrm{p}<0.1,{ }^{* *}, \mathrm{p}<0.05,{ }^{* * *} \mathrm{p}<0.01$.

Source: own study.

In particular, there was no statistically significant difference in preferences regarding spatial disamenities between consumers and pure investors. The age of the household's head proved to be statistically significant in the case of a petrol station - older households seem to be more sensitive (probability of non-acceptance increased with age). The nonacceptance rate increased with the maximum price respondents were willing to pay for their future housing. The variable was statistically significant in the case of a petrol station and noisy road. If we assume this indicator corresponds with the wealth of the household, we can conclude that there is a reason to believe that sensitivity to negative externalities indeed increases with the economic status.

As noted in the literature review, basing the research on SP data has some limitation. The alternative method to address the differences in market preferences between buyers in relation to selected housing attributes, for example the distance to the urban 
green) is a monetary valuation based on RP. While in standard hedonic regression models the assumption of the homogenous population holds, the attributes of buyers can be incorporated in the model. Moreover, in quantile hedonic regression models the differences in implicit prices are investigated in more detail (Davino, Romano, \& Næs, 2015) provided the housing transaction data is available. One particular problem in Poland is that within the housing market setting there is limited information on housebuyers present in typical transaction records.

\section{CONCLUSIONS}

The article addresses the variation in willingness-to-pay for selected spatial amenities and willingness-to-accept spatial disamenities within the housing market context. We investigated the impact of selected positive and negative externalities on housing demand using stated preference data. In particular, we evaluated the importance of economic and demographic characteristics of households for their stated preferences regarding urban green, public transit, retail and services, petrol stations, road noise, and railway lines. We tested three hypothesis using logit models on stated preference data based on housing demand surveys conducted in Krakow from 2012 to 2017.

In general, we observed that relying on simple economic and demographic variables does not help much in understanding the difference in willingness-to-pay for or willingness-to-accept the presence of given (dis)amenities in the neighbourhood (relatively low fit of logit models). We did not observe any significant difference in preferences regarding the proximity of the neighbourhood (dis)amenities regarding the housing purchase motive. In general, respondents planning to buy a flat as a pure investment did not differ from other housebuyers (expressing consumption motives). The findings do suggest that sensitivity to the proximity of neighbourhood (dis)amenities changes with housebuyers' age, but only in some cases, the results were statistically significant (petrol station and public transport). The economic status (proxied by the maximum price households were willing to pay for the future flat) helped to understand differences in preferences regarding the proximity of urban green, petrol station, and road noise. In general, wealthy housebuyers were more sensitive to externalities (higher willingness to pay for amenities, lower willingness to accept disamenities).

Some of the empirical findings must be treated with caution, thus they require future research. We believe that the natural extension of the study is to evaluate the findings using revealed preference from actual market transactions. Provided the detailed sales data is available, the differences in hedonic estimates could be addressed using quantile hedonic regression.

\section{REFERENCES}

Adamowicz, W., Swait, J., Boxall, P., Louviere, J., \& Williams, M. (1997). Perceptions versus Objective Measures of Environmental Quality in Combined Revealed and Stated Preference Models of Environmental Valuation. Journal of Environmental Economics and Management, 32(1), 65-84. https://doi.org/10.1006/jeem.1996.0957

Agostini, C.A., \& Palmucci, G.A. (2008). The anticipated capitalisation effect of a new metro line on housing prices. Fiscal Studies, 29(2), 233-256. https://doi.org/10.1111/j.1475-5890.2008.00074.x 
Ahlfeldt, G.M. (2013). If we build it, will they pay? Predicting property price effects of transport innovations. Environment and Planning A, 45(8), 1977-1994. https://doi.org/10.1068/a45429

Ahlfeldt, G.M., \& Maennig, W. (2013). External Productivity and Utility Effects of City Airports. Regional Studies, 47(4), 508-529. https://doi.org/10.1080/00343404.2011.581652

Anantsuksomsri, S., \& Tontisirin, N. (2015). The Impacts of Mass Transit Improvements on Residential Land Development Values: Evidence from the Bangkok Metropolitan Region. Urban Policy and Research, 33(2), 195-216. https://doi.org/10.1080/08111146.2014.982791

Arrondel, L., \& Lefebvre, B. (2001). Consumption and Investment Motives in Housing Wealth Accumulation: A French Study. Journal of Urban Economics, 50(1), 112-137. https://doi.org/10.1006/juec.2000.2209

Bae, C.-H. C., Jun, M.-J., \& Park, H. (2003). The impact of Seoul's subway Line 5 on residential property values. Transport Policy, 10(2), 85-94.

Beimer, W., \& Maennig, W. (2017). Noise effects and real estate prices: A simultaneous analysis of different noise sources. Transportation Research Part D: Transport and Environment, 54, 282286. https://doi.org/10.1016/j.trd.2017.05.010

Ben-Akiva, M., Mcfadden, D., Train, K., Walker, J., Bhat, C., Bierlaire, M., ... \& Munizaga, M.A. (2002). Hybrid Choice Models: Progress and Challenges. Marketing Letters, 13(3), 163-175. https://doi.org/10.1023/A:1020254301302

Biao, Z., Gaodi, X., Bin, X., \& Canqiang, Z. (2012). The Effects of Public Green Spaces on Residential Property Value in Beijing. Journal of Resources and Ecology, 3(3), 243-252. https://doi.org/10.5814/j.issn.1674-764x.2012.03.007

Brueckner, J.K. (1997). Consumption and Investment Motives and the Portfolio Choices of Homeowners. The Journal of Real Estate Finance and Economics, 15(2), 159-180. https://doi.org/10.1023/A:1007777532293

Chiang, Y.-H., Peng, T.-C., \& Chang, C.-O. (2015). The nonlinear effect of convenience stores on residential property prices: A case study of Taipei, Taiwan. Habitat International, 46, 82-90. https://doi.org/10.1016/j.habitatint.2014.10.017

Cohen, E. (2016), The Nature of Israel's Public Policy Aimed at Curbing the Rise in Property Prices from 2008-2015, as a Derivative of the Country's Governance Structure. Economics and Sociology, 9(2), 73-89. https://doi.org/10.14254/2071-789X.2016/9-2/5

Colwell, P.F., \& Dilmore, G. (1999). Who Was First? An Examination of an Early Hedonic Study. Land Economics, 75(4), 620-626. https://doi.org/10.2307/3147070

Conway, D., Li, C.Q., Wolch, J., Kahle, C., \& Jerrett, M. (2010). A spatial autocorrelation approach for examining the effects of urban greenspace on residential property values. Journal of Real Estate Finance and Economics, 41(2), 150-169. https://doi.org/10.1007/s11146-008-9159-6

Crompton, J.L. (2001). The impact of parks on property values: A review of the empirical evidence. Journal of Leisure Research, 33(1), 1-31. https://doi.org/10.1080/13606710500348060

Czembrowski, P., \& Kronenberg, J. (2016). Hedonic pricing and different urban green space types and sizes: Insights into the discussion on valuing ecosystem services. Landscape and Urban Planning, 146, 11-19. https://doi.org/10.1016/j.landurbplan.2015.10.005

Davino, C., Romano, R., \& Næs, T. (2015). The use of quantile regression in consumer studies. Food Quality and Preference, 40, 230-239. https://doi.org/10.1016/j.foodqual.2014.10.003

Debrezion, G., Pels, E., \& Rietveld, P. (2011). The Impact of Rail Transport on Real Estate Prices: An Empirical Analysis of the Dutch Housing Market. Urban Studies, 48(5), 997-1015. https://doi.org/10.1177/0042098010371395 
de Koning, K., Filatova, T., \& Bin, O. (2017). Bridging the Gap Between Revealed and Stated Preferences in Flood-prone Housing Markets. Ecological Economics, 136, 1-13. https://doi.org/10.1016/j.ecolecon.2017.01.022

Dewees, D.N. (1976). The effect of a subway on residential property values in Toronto. Journal of Urban Economics, 3(4), 357-369. https://doi.org/10.1016/0094-1190(76)90035-8

Dube, J., Theriault, M., \& Des Rosiers, F. (2013). Commuter rail accessibility and house values: The case of the Montreal South Shore, Canada, 1992-2009. Transportation Research Part A: Policy and Practice, 54, 49-66. https://doi.org/10.1016/j.tra.2013.07.015

Franco, S.F., \& Macdonald, J.L. (2016). Measurement and valuation of urban greenness: Remote sensing and hedonic applications to Lisbon, Portugal. Regional Science and Urban Economics. https://doi.org/10.1016/j.regsciurbeco.2017.03.002

Gatzlaff, D., \& Smith, M. (1993). The Impact of the Miami Metrorail on the Value of Residences near Station Locations. Land Economics, 69(1), 54-66. https://doi.org/10.2307/3146278

Geng, B., Bao, H., \& Liang, Y. (2015). A study of the effect of a high-speed rail station on spatial variations in housing price based on the hedonic model. Habitat International, 49, 333-339. https://doi.org/10.1016/j.habitatint.2015.06.005

Gibbons, S., \& Machin, S. (2005). Valuing rail access using transport innovations. Journal of Urban Economics, 57(1), 148-169. https://doi.org/10.1016/j.jue.2004.10.002

Glaeser, E.L., Kolko, J., \& Saiz, A. (2001). Consumer city. Journal of Economic Geography, 1(1), 27-50. https://doi.org/10.1093/jeg/1.1.27

Głuszak, M., \& Marona, B. (2017). Discrete choice model of residential location in Krakow. Journal of European Real Estate Research. 10(1), 4-16. https://doi.org/10.1108/JERER-01-2016-0006

Gómez-Baggethun, E., \& Barton, D.N. (2013). Classifying and valuing ecosystem services for urban planning. Ecological Economics, 86, 235-245. https://doi.org/10.1016/j.ecolecon.2012.08.019

Grislain-Letrémy, C., \& Katossky, A. (2014). The impact of hazardous industrial facilities on housing prices: A comparison of parametric and semiparametric hedonic price models. Regional Science and Urban Economics, 49, 93-107. https://doi.org/10.1016/j.regsciurbeco.2014.09.002

Guignet, D., Jenkins, R., Ranson, M., \& Walsh, P.J. (2018). Contamination and incomplete information: Bounding implicit prices using high-profile leaks. Journal of Environmental Economics and Management, 88, 259-282. https://doi.org/10.1016/j.jeem.2017.12.003

Hendon, W.S. (1971). The Park as a Determinant of Property Values. American Journal of Economics and Sociology, 30(3), 289-300. https://doi.org/10.1111/j.1536-7150.1971.tb03232.x

Herath, S., Choumert, J., \& Maier, G. (2015). The value of the greenbelt in Vienna: A spatial hedonic analysis. Annals of Regional Science, 54(2), 349-374. https://doi.org/10.1007/s00168-015-0657-1

Hoshino, T., \& Kuriyama, K. (2010). Measuring the benefits of neighbourhood park amenities: Application and comparison of spatial hedonic approaches. Environmental and Resource Economics, 45(3), 429-444. https://doi.org/10.1007/s10640-009-9321-5

Ibeas, T., Cordera, R., Dell'Olio, L., Coppola, P., \& Dominguez, A. (2012). Modelling transport and real-estate values interactions in urban systems. Journal of Transport Geography, 24, 370-382. https://doi.org/10.1016/j.jtrangeo.2012.04.012

Irwin, E.G. (2002). The Effects of Open Space on Residential Property Values. Land Economics, 78(4), 465-480. https://doi.org/10.2307/3146847

Jang, M., \& Kang, C.-D. (2015). Retail accessibility and proximity effects on housing prices in Seoul, Korea: A retail type and housing submarket approach. Habitat International, 49, 516-528. https://doi.org/10.1016/j.habitatint.2015.07.004 
Jim, C.Y., \& Chen, W.Y. (2010). External effects of neighbourhood parks and landscape elements on high-rise residential value. Land Use Policy, 27(2), 662-670. https://doi.org/10.1016/j.landusepol.2009.08.027

Johnson, D.B. (1973). Meade, Bees, and Externalities. The Journal of Law and Economics, 16(1), 35-52.

Kim, K., \& Lahr, M.L. (2014). The impact of Hudson-Bergen Light Rail on residential property appreciation. Papers in Regional Science, 93(S1), S79-S97. https://doi.org/10.1111/pirs.12038

Knetsch, J.L. (1964). The Influence of Reservoir Projects on Land Values. Journal of Farm Economics, 46(1), 231. https://doi.org/10.2307/1236486

Kolbe, J., \& Wüstemann, H. (2014). Estimating the Value of Urban Green Space: A hedonic Pricing Analysis of the Housing Market in Cologne, Germany. Acta Universitatis Lodziensis Folia Oeconomica, 5(307).

Koster, H.R., \& Rouwendal, J. (2012). The impact of mixed land use on residential property values. Journal of Regional Science, 52(5), 733-761. https://doi.org/10.1111/j.1467-9787.2012.00776.x

Kumbhakar, S.C., \& Parmeter, C.F. (2010). Estimation of hedonic price functions with incomplete information. Empirical Economics, 39(1), 1-25. http://doi.org/10.1007/s00181-009-0292-8

Lancaster, K.J. (1966). A New Approach to Consumer Theory. Journal of Political Economy, 74(2), 132-157. Retrieved on October 10, 2018 from http://www.jstor.org/stable/1828835

Liou, F.-M., Yang, S.-Y., Chen, B., \& Hsieh, W.-P. (2016). The effects of mass rapid transit station on the house prices in Taipei: The hierarchical linear model of individual growth. Pacific Rim Property Research Journal, 22(1), 3-16. https://doi.org/10.1080/14445921.2016.1158938

MacDonald, D.N., Murdoch, J.C., \& White, H.L. (1987). Uncertain Hazards, Insurance, and Consumer Choice: Evidence from Housing Markets. Land Economics, 63(4), 361-371. https://doi.org/10.2307/3146293

Malpezzi, S. (2002). Hedonic Pricing Models: A Selective and Applied Review. In Housing Economics and Public Policy (pp. 67-89). Blackwell Science Ltd. https://doi.org/10.1002/9780470690680.ch5

Marona, B., \& Wilk, A. (2016). Tenant Mix Structure in Shopping Centres: Some Empirical Analyses from Poland. Entrepreneurial Business and Economics Review, 4(2), 51-65. https://doi.org/10.15678/EBER.2016.040205

Martínez, L.M., \& Viegas, J.M. (2013). A new approach to modelling distance-decay functions for accessibility assessment in transport studies. Journal of Transport Geography, 26, 87-96. https://doi.org/10.1016/j.jtrangeo.2012.08.018

Mayor, K., Lyons, S., Duffy, D., \& Tol, R.S.J. (2012). A hedonic analysis of the value of rail transport in the greater Dublin area. Journal of Transport Economics and Policy, 46(2), 239-261.

McMillen, D.P., \& McDonald, J. (2004). Reaction of House Prices to a New Rapid Transit Line: Chicago's Midway Line, 1983-1999. Real Estate Economics, 32(3), 463-486. https://doi.org/10.1111/j.1080-8620.2004.00099.x

Meade, J.E. (1952). External Economies and Diseconomies in a Competitive Situation. The Economic Journal, 62(245), 54-67. https://doi.org/10.2307/2227173

Mohammad, S.I., Graham, D.J., \& Melo, P.C. (2015). The effect of the Dubai Metro on the value of residential and commercial properties. The Journal of Transport and Land Use, 2(2017), 1-25. https://doi.org/10.5198/jtlu.2017.750

Murphy, J.J., Allen, P.G., Stevens, T.H., \& Weatherhead, D. (2005). A Meta-analysis of Hypothetical Bias in Stated Preference Valuation. Environmental and Resource Economics, 30(3), 313-325. https://doi.org/10.1007/s10640-004-3332-z

Nahman, A. (2011). Pricing landfill externalities: Emissions and disamenity costs in Cape Town, South Africa. Waste Management, 31(9-10), 2046-2056. https://doi.org/10.1016/j.wasman.2011.05.015 
Phaneuf, D.J., Taylor, L.O., \& Braden, J.B. (2013). Combining Revealed and Stated Preference Data to Estimate Preferences for Residential Amenities: A GMM Approach. Land Economics, 89(1), 3052. https://doi.org/10.3368/le.89.1.30

Pope, J.C. (2008). Buyer information and the hedonic: The impact of a seller disclosure on the implicit price for airport noise. Journal of Urban Economics, 63(2), 498-516. https://doi.org/10.1016/j.jue.2007.03.003

Portnov, B.A., Bella, G., \& Barzilay, B. (2009). Investing a timing the Effect of Train Proximity on Apartment Prices: Haifa, Israel as a Case Study. Journal of Real Estate Research, 31(4).

Rodriguez, D.A., \& Targa, F. (2004). Value of accessibility to Bogotá's bus rapid transit system. Transport Reviews, 24(5), 587-610. http://doi.org/10.1080/0144164042000195081

Rosen, S. (1974). Hedonic Prices and Implicit Markets: Product Differentiation in Pure Competition. Journal of Political Economy, 82(1), 34-55. Retrieved on October 10, 2018 from http://www.jstor.org/stable/1830899

Shogren, J.F., Shin, S.Y., Hayes, D.J., \& Kliebenstein, J.B. (1994). Resolving Differences in Willingness to Pay and Willingness to Accept. The American Economic Review, 84(1), 255-270.

Sirmans, S., Macpherson, D., \& Zietz, E. (2005). The Composition of Hedonic Pricing Models. Journal of Real Estate Literature, 13(1), 1-44. https://doi.org/10.5555/reli.13.1.j03673877172w0w2

Song, Y., \& Sohn, J. (2007). Valuing spatial accessibility to retailing: A case study of the single family housing market in Hillsboro, Oregon. Journal of Retailing and Consumer Services, 14(4), 279288. https://doi.org/10.1016/j.jretconser.2006.07.002

Theebe, M.A.J. (2004). Planes, Trains, and Automobiles: The Impact of Traffic Noise on House Prices. The Journal of Real Estate Finance and Economics, 28(2), 209-234. https://doi.org/10.1023/B:REAL.0000011154.92682.4b

Thorsnes, P. (2002). The Value of a Suburban Forest Preserve: Estimates from Sales of Vacant Residential Building Lots. Land Economics, 78(3), 426-441. https://doi.org/10.2307/3146900

Timmermans, H., Molin, E., \& van Noortwijk, L. (1994). Housing choice processes: Stated versus revealed modelling approaches. Netherlands Journal of Housing and the Built Environment, 9(3), 215-227. https://doi.org/10.1007/BF02496997

Trojanek, R., \& Głuszak, M. (2018). Spatial and time effect of subway on property prices. Journal of Housing and the Built Environment, 33(2), 359-384. https://doi.org/10.1007/s10901-017--9569-y

Trojanek, R., Gluszak, M., \& Tanas, J. (2018). The effect of urban green spaces on house prices in Warsaw. International Journal of Strategic Property Management, 22(5), 358-371. https://doi.org/10.3846/ijspm.2018.5220

Troy, A., Grove, J.M., \& Grove, J.M. (2008). Property values, parks, and crime: a hedonic analysis in Baltimore, MD. MD. Landscape and Urban Planning, 87.

Tyrväinen, L., \& Miettinen, A. (2000). Property Prices and Urban Forest Amenities. Journal of Environmental Economics and Management, 39(2), 205-223. https://doi.org/10.1006/jeem.1999.1097

Votsis, A. (2017). Planning for green infrastructure: The spatial effects of parks, forests, and fields on Helsinki's apartment prices. Ecological Economics, 132, 279-289. https://doi.org/10.1016/j.ecolecon.2016.09.029

Whitehead, J.C., Pattanayak, S.K., Van Houtven, G.L., \& Gelso, B.R. (2008). Combining revealed and stated preference data to estimate the nonmarket value of ecological services: an assessment of the state of the science. Journal of Economic Surveys, 22(5), 872-908. https://doi.org/10.1111/j.1467-6419.2008.00552.x 
Zhou, X., Gibler, K., \& Zahirovic-Herbert, V. (2015). Asymmetric buyer information influence on price in a homogeneous housing market. Urban Studies, 52(5), 891-905. https://doi.org/10.1177/0042098014529464

Zieba, M., Belniak, S., \& Głuszak, M. (2013). Demand for sustainable office space in Poland: the results from a conjoint experiment in Krakow. Property Management, 31(5), 404-419. Retrieved on October 10, 2018 from https://www.emeraldinsight.com/doi/full/10.1108/PM-11-2012-0039?fullSc=1

Źróbek, S., Trojanek, M., Źróbek-Sokolnik, A., \& Trojanek, R. (2015). The influence of environmental factors on property buyers' choice of residential location in Poland. Journal of International Studies, 7(3), 163-173.

\section{Author}

\section{Michał Głuszak}

PhD in Economics (Cracow University of Economics); Master in Sociology (Jagiellonian University in Krakow). Michal Gluszak currently works as an Assistant Professor at the Department of Real Estate and Investment Economics, Cracow University of Economics. He does research in Microeconomics, Public Economics, Urban Economics and Real Estate Economics.

Correspondence to: Michał Głuszak, PhD, Cracow University of Economics, Department of Real Estate and Investment Economics, ul. Rakowicka 27, 31-510 Krakow, Poland, e-mail: gluszakm@uek.krakow.pl

\section{Acknowledgements and Financial Disclosure}

Michal Głuszak acknowledges financial support from the funds allocated to development of research potential of the Faculty of Economics and International Relations of the Cracow University of Economics for 2018.

\section{Copyright and License}

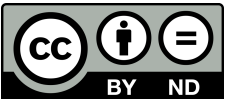

This article is published under the terms of the Creative Commons Attribution - NoDerivs (CC BY-ND 4.0) License http://creativecommons.org/licenses/by-nd/4.0/

\section{Published by the Centre for Strategic and International Entrepreneurship - Krakow, Poland}

